\title{
CLINICAL-FUNCTIONAL VULNERABILITY IN OLDER ADULTS AND ITS IMPACT ON PRIMARY HEALTH CARE ACTIONS
}

\section{Vulnerabilidade clínico-funcional em idosos e seu impacto para ações na atenção primária à saúde}

\section{Vulnerabilidad clínico-funcional de mayores y su impacto en las acciones de la atención primaria de salud}

Pricila Cristina Correa Ribeiro iD

Federal University of Minas Gerais (Universidade Federal de Minas Gerais) - Belo Horizonte (MG) - Brazil

Andréia Cleide Costa Neves (iD

Belo Horizonte Prefectural Government (Prefeitura Municipal de Belo Horizonte) - Belo Horizonte (MG) - Brazil

Juliana do Carmo Reis (iD

Belo Horizonte Prefectural Government (Prefeitura Municipal de Belo Horizonte) - Belo Horizonte (MG) - Brazil

André Luiz Almeida Damaso (iD)

Federal University of Minas Gerais (Universidade Federal de Minas Gerais) - Belo Horizonte (MG) - Brazil

Vanessa Cunha Barros (iD

Federal University of Minas Gerais (Universidade Federal de Minas Gerais) - Belo Horizonte (MG) - Brazil

\begin{abstract}
Objective: To describe the prevalence of clinical-functional vulnerability among older adults cared for in a Primary Health Care Unit (PHCU). Methods: This is a retrospective epidemiological study performed through the review of medical records of 950 elderly users of a PHCU in the northeast region of Belo Horizonte, between August 2016 and July 2017. The score obtained with use of the Clinical-functional Vulnerability Index (IVCF-20) evidenced the clinical-functional vulnerability of the older adults. The PHCU health professionals had been trained and had been implementing the IVCF-20 since the end of 2015. In 2016, the application of IVCF-20 was intensified following training of psychology undergraduates who participated in the Health Work Education Program (Programa de Educação pelo Trabalho para a Saúde - PET-Saúde). Descriptive statistics was applied to IVCF-20 data to verify the frequency of frail older adults and individuals at risk for frailty. Pearson's chi-square test was used to verify association between the IVCF-20 classification and the Family Health Teams. Results: Of 950 older adults included in the study, $49.37 \%$ ( $n=469)$ had mild clinical-functional vulnerability, considered robust; $28.84 \%(n=274)$ had moderate vulnerability, considered at risk for frailty; and $21.79 \%(n=207)$ had high vulnerability, regarded as frail. Conclusion: A high prevalence of clinical-functional vulnerability (mild, moderate, and high) was observed among older adults attended to at primary health care services. Screening with IVCF-20 can prove useful for early identification of vulnerable older adults and to indicate the focus of health promotion and preventive interventions.
\end{abstract}

Descriptors: Primary Health Care; Health of the Elderly; Frail Older Adult.

\section{RESUMO}

Objetivo: Descrever a prevalência de vulnerabilidade clínico-funcional em idosos atendidos em uma Unidade Básica de Saúde (UBS). Métodos: Trata-se de um estudo epidemiológico retrospectivo realizado com a revisão dos prontuários de 950 idosos usuários de uma UBS, na região nordeste de Belo Horizonte, atendidos entre agosto de 2016 e julho de 2017 . O escore do Índice de Vulnerabilidade Clínico-Funcional (IVCF-20) forneceu a vulnerabilidade funcional do idoso. Capacitaram-se os profissionais de saúde da UBS e implantou-se o IVCF-20 desde o final de 2015. Em 2016, ampliou-se a aplicação do IVCF-20 com o treinamento de graduandos de psicologia que participaram do Programa PET-Saúde. Realizou-se estatística descritiva com os dados do IVCF-20 para verificar a frequência de idosos frágeis ou em risco de fragilidade. Utilizou-se o qui-quadrado de Pearson para verificar a associação da classificação do IVCF-20 com a Equipe de Saúde da Família. Resultados: Dos

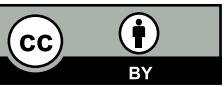


950 idosos, 49,37\% (n=469) apresentavam baixa vulnerabilidade clínico-funcional, considerados robustos; $28,84 \%$ ( $n=274)$ apresentavam média vulnerabilidade, considerados em risco de fragilidade e $21,79 \%(n=207)$ apresentavam alta vulnerabilidade, tidos como frágeis. Conclusão: Observou-se elevada prevalência de vulnerabilidade clínico-funcional (baixa, média e alta) entre os idosos atendidos na atenção primária à saúde. O rastreio com o IVCF-20 pode ser útil para a identificação precoce dos idosos clinicamente vulneráveis e para indicar o foco de intervenções preventivas e de promoção da saúde.

Descritores: Atenção Primária à Saúde; Saúde do Idoso; Idoso Fragilizado.

\section{RESUMEN}

Objetivo: Describir la prevalencia de la vulnerabilidad clínico-funcional entre los mayores asistidos por la Unidad Básica de Salud (UBS). Métodos: Estudio epidemiológico y retrospectivo realizado a través de una revisión de historiales clínicos de 950 usuarios mayores de la UBS de la región nordeste de Belo Horizonte entre agosto de 2016 y julio de 2017. La puntuación obtenida con el uso del Clinical-functional Vulnerability Index (IVCF-20) ha evidenciado la vulnerabilidad clínico-funcional de mayores. Los profesionales sanitarios de la UBS han sido entrenados y se ha puesto en marcha la IVCF-20 desde finales de 2015. En 2016 la aplicación del IVCF-20 ha sido intensificada con el entrenamiento de estudiantes de psicología que han participado del Health Work Education Program (Programa de Educación por el Trabajo para la Salud) - PET-Salud). La estadística descriptiva ha sido aplicada para los datos del IVCF-20 para verificar la frecuencia de mayores frágiles e individuos con riesgo de fragilidad. La prueba de Chi-cuadrado ha sido utilizada para verificar la asociación entre la clasificación del IVCF-20 y los Grupos de Salud de la Familia. Resultados: De los 950 mayores incluidos en el estudio, el 49,37\% ( $n=469)$ tenían vulnerabilidad clínico-funcional leve y eran considerados fuertes; el $28,84 \%(n=274)$ tenían moderada vulnerabilidad y eran considerados de riesgo para la fragilidad y el 21,79\% ( $n=207)$ tenían alta vulnerabilidad y eran considerados frágiles. Conclusión: Una elevada prevalencia de vulnerabilidad clínico-funcional (leve, moderada y alta) ha sido observada entre los mayores asistidos en los servicios de cuidados primarios de salud. Investigación con el IVCF-20 puede ser útil para la identificación precoz de mayores vulnerables e indicar el foco de las intervenciones de prevención y de promoción de la salud.

Descriptores: Atención Primaria de Salud; Salud del Anciano; Anciano Frágil.

\section{INTRODUCTION}

Population aging is a phenomenon observed in our society and is considered an achievement of humanity in the twentieth century. However, there are many challenges for aging to happen in a healthy way, and this is an issue of concern in various levels of public health care. With an estimate that $73 \%$ of the elderly population in Brazil is attended to by the Unified Health System (Sistema Único de Saúde - SUS), the Ministry of Health launched the Personal Health Record for Older Adults, which includes a set of initiatives aimed at qualifying the care provided for elderly people ${ }^{(1)}$.

According to the Ministry of Health(2), about $30 \%$ of the elderly can be classified as frail or at risk of frailty, which means greater vulnerability, more frequent states of disability, functional dependencies, or health conditions that represent the need for access and more qualified care within SUS. Thus, it is urgent that effective strategies be implemented in the identification and treatment of older adults at risk of frailty from the demand for Primary Health Care services ${ }^{(3)}$.

Although frailty is a common condition associated with aging, this condition appears quite heterogeneously among individuals of roughly the same age. Health in the elderly comprises maintaining independence for satisfaction of biopsychosocial needs even with advancement of age or when pathological conditions are present ${ }^{(4)}$. Fragilization refers to the functional decline that falls on those needs; biological, individual, and social factors are related to this process, which results in loss of autonomy or independence in activities of daily living. Given this, it is important to consider the elderly comprehensively through the multiplicity of aspects that influence health and quality of life, such as the preservation of functional capacity, autonomy, social participation, cognition, and self-perception of health status ${ }^{(5)}$.

In the context of geriatric care, the search for instruments capable of scaling the level of vulnerability of patients and its determining factors is increasing, since this strategy is indicated for optimization of services and resources of the health system in assisting the elderly population ${ }^{(6-8)}$. Specifically in the context of primary care, for early detection of geriatric syndromes, it is necessary to use quick and simple instruments, applied by professionals from several health fields ${ }^{(4,9,10)}$. Additionally, in the national and international context, conducting health assessments and screening for medical conditions of the elderly population in the primary health care level have been suggested as strategies to guide the elaboration of interventions based on identification and monitoring of groups that demand differentiated care $^{(4,11)}$. Thus, through the implementation of monitoring and interventions based on the clinical-functional profile of 
the elderly population, it is possible to prevent or delay the onset of disability and dependence in this group, increasing their chances to maintain an active aging and better quality of life ${ }^{(12,13)}$.

A multidimensional evaluation of the factors associated with frailty in older adults enables the appropriate referral of risk groups for specialized evaluation. Among the instruments reported in the literature for this multidimensional assessment, the Clinical-functional Vulnerability Index-20 (Índice de Vulnerabilidade Clínico-funcional - IVCF-20) can be considered a simple geriatric assessment tool, whose objective is a specialized evaluation of older adults, aiming to identify their degree of clinical vulnerability.

A study with a group of older adults from Belo Horizonte, Minas Gerais (MG)(4) found significant correlations between IVCF-20 results and the Comprehensive Geriatric Assessment, and concluded that, although it does not replace the specialized care provided by a geriatric/gerontological team - a work that demands higher costs and time - IVCF-20 is a tool that articulates the strategy of comprehensive assessment of older adults' health with the viability in primary health care settings.

To describe the prevalence of clinical-functional vulnerability among older adults cared for in a Primary Health Care Unit (PHCU) in order to trace their demands and assist in the planning of interventions.

\section{METHODS}

This is a retrospective epidemiological study performed with the review of medical records of elderly users of a Primary Health Care Unit (PHCU) in the northeast region of Belo Horizonte, Minas Gerais, Brazil. The PHCU is responsible for the primary care of 12,195 low-income users, of which 6,409 are female, and 5,786 are male. Adults make up the majority $(60.14 \%)$ of the described population. The elderly population corresponds to $16.33 \%(n=1991)$ of users cared for in the PHCU. The PHCU has four Family Health Teams (FHT), which are identified as Red, Blue, Yellow, and Green; two Dentistry Teams; a Family Health Support Center (psychologist, physiotherapist, pharmacist, nutritionist, speech therapist, physical educator); and a Mental Health Team (psychologist, psychiatrist and social worker), in addition to Support professionals (nurse, physician and pediatrician). This information was provided by the Department of Health of Belo Horizonte - SMSA/BH.

The Green FHT serves 458 (23.83\%) users, of whom 275 are female, and 183 are male. The Blue FHT serves $440(22.89 \%)$ users, 263 female and 177 male. The Red FHT attends to 460 (23.34\%) users, 260 female and 200 male, and the Yellow FHT serves $564(29.34 \%)$ users, 339 female and 225 male. There is a similar percentage of elderly users in all FHTs, with a predominance of women. This information was provided by the Department of Health of Belo Horizonte - SMSA/BH).

The IVCF-20 application for screening for clinical-functional vulnerability, during the study period, was performed with a total of 950 older adults, and these were included in the present study sample, corresponding to $49.28 \%$ of the elderly population attended to in the PHCU, with $228(22 \%)$ served by the Red team; $209(22 \%)$ by the Green team; $271(28.5 \%)$ by the Blue team, and $242(25.4 \%)$ by the Yellow team.

To obtain data from the Clinical-functional Vulnerability Index (IVCF-20), the medical records of the elderly population attended at the PHCU in the period from August 2016 to July 2017 were reviewed. Besides the medical records, additional data was obtained, such as sex and FHT responsible for attending to the patient.

The IVCF-20 is a multidimensional evaluation of the elderly and proposes a risk classification of frailty based on 20 questions, distributed into eight sections: age (1 question), self-perception of health (1 question), functional disabilities (4 questions), cognition (3 questions), mood (2 questions), mobility (6 questions), communication (2 questions), and multiple comorbidities (1 question), which can be answered by the elderly or an accompanying person. The tool enables the completion of a brief evaluation of the functionality of the older adult and can be applied by any health professional ${ }^{(14)}$. The maximum score is 40 points, and the higher the score, the greater the clinical-functional vulnerability risk of the elderly. To characterize the clinical-functional vulnerability of the elderly, the following classification criteria from the IVCF-20 total score were used: a) 0 to 6 points - mild vulnerability; b) 7 to 14 points - moderate vulnerability, indicating risk of frailty; c) 15 or more points - high vulnerability, indicating frailty ${ }^{(14)}$.

The PHCU health professionals, including the Community Health Workers (CHWs) and other professionals from the Family Health Support Center (Núcleos de Apoio à Saúde da Família - NASF) had been trained and had been implementing the IVCF-20 since the end of 2015. In order to intensify data collection during the period of interest of the study, in 2016, psychology undergraduates who participated in the Health Work Education Program (Programa de Educação pelo Trabalho para a Saúde - PET-Saúde) were trained to apply IVCF-20 to the elderly in the area of comprehensiveness. IVCF-20 questionnaires were applied at the health unit, when the elderly attended for consultations and/or pick up medication, or during group reunions, such as on the "Elderly Day", organized to receive at the unit a 
large flow of elderly users. These data collections also occurred during home visits made by the CHWs. Thus, it is understood that the data, recorded in the IVCF-20 chart, were adequate to fulfill the research objectives.

Descriptive statistics were conducted with the IVCF data to verify the frequency of robust elderly and individuals at risk of frailty, according to the FHT. The Pearson's chi-square test was used to verify association of the IVCF classification according to sex and the FHT. Statistical analyses were performed using the Statistical Package for Social Sciences (SPSS), version 20.0.

Prior to conducting the study, consent was obtained from the Education Management in Health, linked to the Department of Health of Belo Horizonte, and it was approved by the Ethics Committee in Research Involving Human Subjects of the same Department (Number: 2.448.462, CEP-SMSA/BH).

\section{RESULTS}

The medical records of 950 older adults were analyzed, covering $49.28 \%$ of the elderly population cared for in the PHCU, being 621 (65.37\%) women and 329 (34.63\%) men. The distribution of this sample according to gender and age was described in Table I, according to the FHT that serves this population at the PHCU.

It was observed that there was no statistically significant difference for the variable gender ( $p$-value $=0.87$ ), but there was a difference in the proportion of age groups $(p=0.02)$ in the elderly attended to by FHT. Comparing these characteristics of the elderly between the FHTs, it was observed that the highest proportion of older adults aged up to 74 years $(20.74 \%)$ was in the Blue team; the highest proportion of older adults aged $75-84$ years $(8.42 \%)$ was in the Yellow team; and the lowest proportion of older adults over 85 years old $(1.58 \%)$ was also in the Yellow team.

Table I - Distribution of the older adults in the sample according to sex and age by PHCU Family Health Team. Belo Horizonte, Minas Gerais, Brazil, 2016 - 2017.

\begin{tabular}{|c|c|c|c|c|c|c|}
\hline Distribution & $\begin{array}{c}\text { Red } \\
\mathrm{n}(\%)\end{array}$ & $\begin{array}{l}\text { Green } \\
\text { n (\%) }\end{array}$ & $\begin{array}{l}\text { Blue } \\
n(\%)\end{array}$ & $\begin{array}{c}\text { Yellow } \\
\text { n (\%) }\end{array}$ & Total & p-value ${ }^{*}$ \\
\hline \multicolumn{7}{|l|}{ Age group } \\
\hline $60-74$ years & 158 (16.63) & $140(14.74)$ & $197(20.74)$ & 147 (15.47) & $636(67.58)$ & \\
\hline $75-84$ years & $50(5.26)$ & $51(5.37)$ & $51(5.37)$ & $80(8.42)$ & $232(24.42)$ & 0.02 \\
\hline$>85$ years & $20(2.11)$ & $18(1.89)$ & $23(2.42)$ & $15(1.58)$ & $76(8.0)$ & \\
\hline \multicolumn{7}{|l|}{ Gender } \\
\hline Female & 149 (15.58) & $141(14.84)$ & 177 (18.63) & $154(16.21)$ & $621(65.37)$ & 0.87 \\
\hline Male & $79(8.23)$ & $68(7.16)$ & $94(9.89)$ & $88(9.26)$ & 329 (34.63) & \\
\hline
\end{tabular}

"Obtained through Pearson's Chi-Square Test

The Clinical-functional Vulnerability classification, according to the IVCF-20 total score, showed that $21.79 \%$ $(n=207)$ presented high vulnerability, classified as frail; $28.84 \%(n=274)$ presented moderate vulnerability, classified as at risk for frailty, and $49.37 \%(n=469)$ of the elderly had mild clinical-functional vulnerability, classified as robust. The distribution of this classification by FHT can be seen in Figure 1.

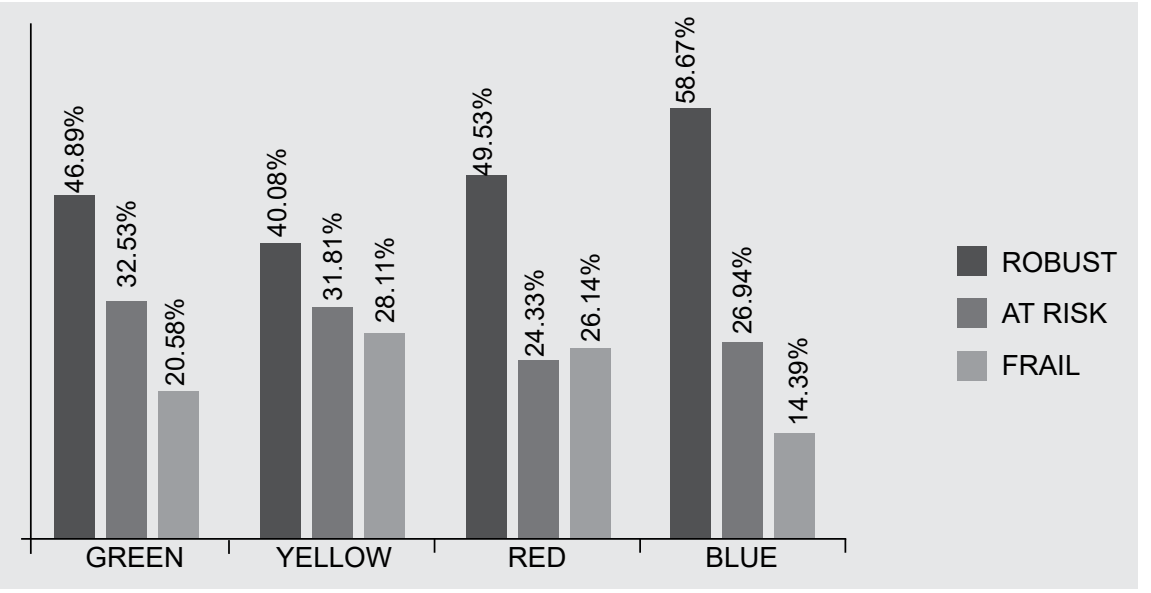

Figure 1 - Prevalence of the Clinical-functional Vulnerability classification of the elderly according to the PHCU Family Health Team. Belo Horizonte, Minas Gerais, Brazil, 2016 - 2017. 
The Yellow FHT stood out with the highest proportion of frail older adults $(28.11 \%, \mathrm{n}=68)$. On the other hand, The Blue FHT stood out with the highest proportion of robust older adults $(58.67 \%, n=159)$, obtaining lower averages in the vulnerability indicators, evaluated in the IVCF-20 dimensions, in comparison to those obtained by the elderly population of the Unit. Tables II and III summarize the distribution of the elderly according to the responses in each clinical dimension evaluated with use of IVCF-20. These results were described by FHT.

Table II shows Red and Yellow FHTs with the highest percentages of older adults with negative self-perception of health, indicated by a score of 1 in this dimension. Regarding the item Activities of daily living (ADL), there was predominance of score 0 , which indicates absence of decline in activities of daily living. However, the results of the Yellow FHT stood out, showing the highest percentage of elderly people who scored a loss in the three instrumental ADL evaluated, namely: stop shopping, stop controlling their own money, and stop doing small housework. The Red FHT was distinguished by presenting the highest percentage of elderly people who stopped doing the self-care.

With regard to cognitive aspects, Red FHT was highlighted as the only one with a percentage above $50 \%$ ( $n=114$ ) of elderly people with a complaint of forgetfulness, such as saying that it has been worsening in the last months and/ or that it is preventing performance of everyday activities. In contrast, the Green FHT had $67.94 \%(n=142)$ of elderly people without complaints of forgetfulness.

Regarding mood, Red and Yellow FHTs stood out for obtaining a percentage of $22.80 \%(n=52)$ and $19.42 \%$ $(n=47)$, respectively, of older adults who reported symptoms of discouragement, sadness or hopelessness, and loss of interest/pleasure in activities that were once considered pleasurable.

Table II - Distribution of the older adults by their scores in the IVCF-20 dimensions Self-perception of health, Activities of daily living, Cognition, and Mood, according to the Family Health Team of the PHCU. Belo Horizonte, Minas Gerais, Brazil, 2016 - 2017.

\begin{tabular}{|c|c|c|c|c|c|c|}
\hline $\begin{array}{l}\text { Clinical dimensions } \\
\text { assessed by the IVCF }\end{array}$ & Score ${ }^{*}$ & $\begin{array}{l}\text { Red } \\
\mathrm{n}(\%)\end{array}$ & $\begin{array}{c}\text { Green } \\
\mathrm{n}(\%)\end{array}$ & $\begin{array}{l}\text { Blue } \\
\text { n (\%) }\end{array}$ & $\begin{array}{c}\text { Yellow } \\
\mathrm{n}(\%)\end{array}$ & $\begin{array}{l}\text { Total } \\
\text { n (\%) }\end{array}$ \\
\hline \multirow[t]{2}{*}{ Self-perception of health } & 0 & $135(59.21)$ & $133(63.64)$ & $209(77.12)$ & $146(60.33)$ & $618(65.4)$ \\
\hline & 1 & $93(40.79)$ & $76(36.36)$ & $62(22.88)$ & $96(39.67)$ & $326(34.6)$ \\
\hline \multicolumn{7}{|l|}{ Activities of daily living } \\
\hline & 0 & $165(74.32)$ & $154(73.68)$ & $216(80.00)$ & $166(71.24)$ & $701(74.15)$ \\
\hline & 4 & $35(15.77)$ & $40(19.14)$ & $40(14.81)$ & $61(26.18)$ & $176(18.64)$ \\
\hline & 6 & $2(0.9)$ & $3(1.44)$ & $2(0.74)$ & $1(0.43)$ & $8(0.85)$ \\
\hline & 10 & $20(9.01)$ & $12(5.74)$ & $12(4.44)$ & $5(2.15)$ & $59(6.36)$ \\
\hline \multicolumn{7}{|l|}{ Cognition } \\
\hline & 0 & $108(48.65)$ & $142(67.94)$ & $170(62.73)$ & $134(55.37)$ & $554(58.65)$ \\
\hline & 1 & $52(23.42)$ & $19(9.09)$ & 39 (14.39) & $53(21.9)$ & $163(17.3)$ \\
\hline & 2 & $21(9.46)$ & $26(12.44)$ & $35(12.92)$ & $23(9.5)$ & $105(10.97)$ \\
\hline & 3 & $5(2.25)$ & $2(0.96)$ & $6(2.21)$ & $3(1.24)$ & $16(77.7)$ \\
\hline & 4 & $36(16.22)$ & $20(9.57)$ & $21(7.75)$ & $29(11.98)$ & $106(11.39)$ \\
\hline \multicolumn{7}{|l|}{ Mood $^{\prime+\cdots+}$} \\
\hline & 0 & $131(57.46)$ & $121(57.89)$ & $169(62.36)$ & $127(52.48)$ & $542(57.36)$ \\
\hline & 2 & $45(19.74)$ & $54(25.84)$ & $69(25.46)$ & $68(28.10)$ & $233(24.58)$ \\
\hline & 4 & $52(22.80)$ & $34(16.27)$ & $33(12.18)$ & $47(19.42)$ & $169(17.80)$ \\
\hline
\end{tabular}

"Some score categories were grouped because of the small sample size in the category. " $p>0.001 ;{ }^{* * * *} p>0.01 ;{ }^{* * * *} p>0.05$

Regarding mobility, there was a slight overlap of losses in this dimension for older adults of the Yellow FHT. It was verified, for example, that $9.5 \%(n=23)$ of the elderly served by this team scored difficulty holding small objects, compared to an average percentage of $5.52 \%(n=13)$ of other FHTs. Another aspect of the multifunctional evaluation, for which the Yellow FHT presented the highest percentage of older adults with losses, was communication. In this IVCF-20 dimension, complaints of loss of visual and auditory acuity, sufficient to prevent some daily activity, are evaluated and, for the elderly of the Yellow team, $53.31 \%(n=129)$ and $24.38 \%(n=59)$, respectively, presented these complaints. 
Table III - Distribution of the older adults by their scores in the IVCF-20 dimensions Mobility, Communication and Comorbidities, according to the Family Health Team of the PHCU. Belo Horizonte, Minas Gerais, Brazil, 2016 2017.

\begin{tabular}{|c|c|c|c|c|c|c|}
\hline $\begin{array}{l}\text { Clinical dimensions assessed by the } \\
\text { IVCF }\end{array}$ & Score $^{*}$ & $\begin{array}{l}\text { Red } \\
n(\%)\end{array}$ & $\begin{array}{l}\text { Green } \\
n(\%)\end{array}$ & $\begin{array}{l}\text { Blue } \\
\text { n (\%) }\end{array}$ & $\begin{array}{c}\text { Yellow } \\
\text { n (\%) }\end{array}$ & $\begin{array}{l}\text { Total } \\
\text { n (\%) }\end{array}$ \\
\hline \multirow[t]{5}{*}{ Mobility $^{* * * *}$} & $0-1$ & $131(59.21)$ & $108(51.67)$ & $158(58.3)$ & 107 (44.21) & 499 (52.86) \\
\hline & $2-3$ & $45(19.74)$ & $59(28.23)$ & 73 (26.94) & $62(25.62)$ & 241 (25.53) \\
\hline & $4-5$ & $22(9.65)$ & 26 (12.44) & 26 (9.59) & $40(16.53)$ & 116 (12.29) \\
\hline & $6-7$ & $13(5.70)$ & $13(6.22)$ & $11(4.06)$ & $25(10.33)$ & 63 (6.67) \\
\hline & $8-10$ & $13(5.70)$ & $3(1.44)$ & $3(1.11)$ & $8(3.31)$ & $25(2.65)$ \\
\hline \multirow[t]{3}{*}{ Communication } & 0 & $172(75.44)$ & $142(67.94)$ & $221(81.55)$ & $91(37.60)$ & $620(65.68)$ \\
\hline & 2 & 45 (19.74) & $48(22.97)$ & $40(14.76)$ & $114(47.11)$ & $245(25.85)$ \\
\hline & 4 & $11(4.82)$ & $19(9.09)$ & $10(3.69)$ & 37 (15.29) & 79 (8.47) \\
\hline \multicolumn{7}{|l|}{ Comorbidities } \\
\hline & 0 & $109(47.81)$ & $107(51.2)$ & 161 (59.41) & $127(52.48)$ & 505 (53.39) \\
\hline & $2-4$ & 119 (52.19) & $102(48.8)$ & 110 (40.59) & 115 (47.52) & 439 (46.61) \\
\hline
\end{tabular}

* Some score categories were grouped because of the small sample size in the category; ${ }^{* *} p>0.001 ;{ }^{* * *} p>0.01 ;{ }^{* * *} p>0.05$

\section{DISCUSSION}

The results showed a high prevalence of elderly individuals at risk for frailty and frail, $28.84 \%(n=274)$ and $21.79 \%$ $(n=208)$, respectively. These findings are compatible with results of other studies carried out in the context of public health, which showed an expressive percentage of older adults with high or moderate clinical-functional vulnerability ${ }^{(9)}$.

One of the FHTs, Blue, stood out with an expressive proportion of robust older adults $(58.67 \%$; $n=159)$, which may be associated with the fact that the subgroup of older adults attended to by this team corresponds to a younger population, with a higher concentration of older adults in the age group of 60 to 74, compared to those of the other teams. The increase in age is recognized as the main risk factor for several diseases measured by IVCF-20, such as falls, cognitive and functional losses, as well as for other geriatric syndromes associated with severe impairments in old age ${ }^{(3,4)}$.

In the present study, there was a high prevalence of positive self-perception of health; $58.56 \%$ of the older adults perceived their health as excellent, very good, or good. This favorable perception about their own health has been widely reported in the technical literature ${ }^{(15,16)}$, including studies with older adults assisted in primary care ${ }^{(17,18)}$. From this understanding that self-perception of health in the elderly tends to be positive, it can be assumed that the worsening of this self-perception represents a relevant indicator of health alterations that can be easily obtained and monitored by the FHT. In addition, it is known that negative self-perception of health is related to adverse outcomes in old age such as disability and mortality ${ }^{(19,20)}$. In a study ${ }^{(21)}$ with a sample of older adults from Belo Horizonte, Minas Gerais, Brazil, attended to at a Reference Center in elderly care, at the secondary health care level, obtained a prevalence of $70.1 \%(n=218)$ of negative self-perception of health and evidenced that this was associated with impaired autonomy and independence.

In the present study, the high percentage of older adults who presented symptoms of depression was also highlighted, and the FHT subgroups Red and Yellow presented the highest number of older adults with this condition. Depression symptoms in the elderly may negatively impact adherence to health care ${ }^{(22)}$ and increase the risk for frailty ${ }^{(23)}$. In this same direction, there was a high prevalence of cognitive impairment complaints among the older adults studied. Screening and monitoring the cognitive dimension of elderly public service users is regarded as a key strategy for early detection and treatment of cognitive impairment in this population ${ }^{(24,25)}$. Therefore, it is understood that, in the care offered to the elderly at the primary health care level, it is necessary to identify and guarantee the treatment of psychological damages, including the articulation with specialized services ${ }^{(14)}$, as well as assuming preventive strategies on cognitive decline and mental health promotion in old age ${ }^{(14)}$.

Recommendations and worldwide evidences indicate that health policies which prioritize strategies to strengthen preventive health care in the elderly have obtained better economic results and effectiveness in controlling negative health outcomes in this population ${ }^{(8)}$. In the context of public health, epidemiological data plays an important role in the 
prevention of adverse events and enables early diagnosis and intervention ${ }^{(11)}$. More effective policies and guidelines for prevention strategies are obtained from the management of chronic health conditions of a given population, as well as the factors associated with these conditions ${ }^{(26,27)}$. In this sense, the results of the present study were shared with the FHTs of the health unit from which the study population was extracted, so that these professionals could use the classification of clinical-functional vulnerability to draw follow-up and intervention strategies for the older adults.

With regard to the most significant results, the impairment level in mobility and communication of the older adults under their care was alarming for the Yellow team, and it is assumed that these indicators should be more focused on interventions offered by this team. For the Red team, the expressive number of users who stopped doing self-care was unexpected, as well as the higher proportion of older adults with high vulnerability in the memory domain.

Despite these results, the team opted to prioritize the older adults at risk for frailty in their actions planned for 2018 , aiming to prevent cognitive and functional decline in the elderly population. Although old age is associated with the probability of developing diseases, vulnerability and dependence conditions, there is a large part of the elderly population that does not require highly complex interventions, but demands care aimed at preventing functional losses and controlling non-disabling chronic diseases ${ }^{(28)}$. Thus, efficient models for health loss prevention in older adults should include actions aimed at postponing and controlling chronic diseases and maintaining functional capacity ${ }^{(29)}$.

The impact of the present study on actions in the health care unit can be observed from two projects elaborated by the Red FHT. One of these projects, based on the methodology of the Operational Group ${ }^{(30)}$ and with participation of a multiprofessional team, provided interventions with the elderly identified as at risk for frailty. The intervention sought, from specific cognitive and functional stimulation activities, conducted in six weekly meetings, to improve the acquisition and retention of memory, as well as the teaching of strategies for daily use aimed at improving global cognitive functionality. The other intervention for older adults at risk for frailty was focused on mobility, being carried out by a NASF physiotherapist assisted by a team of trainees, and included the accomplishment of five meetings in which educational actions, prescriptions, and exercises were addressed.

The present investigation was limited to the description of the clinical-functional profile of older adults in a health care unit and did not investigate contextual factors that may be associated with vulnerability in this population. Thus, it is pointed out the need for future research on socio-environmental factors of the different coverage areas that may intensify vulnerability conditions of this elderly population ${ }^{(30)}$.

\section{CONCLUSION}

The present study showed high prevalence of clinical-functional vulnerability in older adults and pointed out the indicators of this vulnerability that need to become focus of interventions in primary health care, such as cognitive and functional impairments, and mood changes. Health prevention and promotion surpass the bias towards curative care and represent a solution in the control of increased risk of chronic and degenerative pathological affections associated with aging.

\section{CONFLICTS OF INTEREST}

There are no conflicts of interest.

\section{CONTRIBUTIONS}

Pricila Cristina Correa Ribeiro contributed to the study conception and design; analysis and interpretation of data; and writing and revision of the manuscript. Andréia Cleide Costa e Neves and Juliana do Carmo Reis contributed to the study conception and design; supervision of data acquisition; analysis and interpretation of data; and writing the manuscript. André Luiz Almeida Damaso and Vanessa Cunha Barros contributed to the acquisition, analysis and interpretation of data; and writing the manuscript.

\section{FUNDING SOURCES}

Brazilian National Council for Scientific and Technological Development (CNPq) - Brasil, Grant No: 434824/2018-6.

\section{REFERENCES}

1. Ministério da Saúde (BR). Secretaria de Atenção à Saúde. Departamento de Atenção Especializada e Temática. Caderneta de Saúde da Pessoa Idosa. 4ª . ed. Brasília: Ministério da Saúde; 2017. 
2. Ministério da Saúde (BR). Diretrizes para o cuidado das pessoas idosas no SUS: proposta de modelo de atenção integral [Internet]. Brasília: Ministério da saúde; 2014. [acesso em 2018 Set 03]. Disponível em: http://bvsms.saude.gov.br/bvs/publicacoes/diretrizes_cuidado_pessoa_idosa_sus.pdf

3. Buckinx F, Rolland Y, Reginster JY, Ricour C, Petermans J, Bruyère O. Burden of frailty in the elderly population: perspectives for a public health challenge. Archives of Public Health. 2015;73(1):19.

4. Moraes EN, Carmo JA, Moraes FL, Azevedo RS, Machado CJ, Montilla DER. Índice de Vulnerabilidade Clínico Funcional-20 (IVCF-20): reconhecimento rápido do idoso frágil. Rev Saúde Pública. 2016;50(81):1-10.

5. Pedreira RBS, Rocha SV, Santos CA, Vasconcelos LRC, Reis MC. Validade de conteúdo do instrumento de avaliação da saúde do idoso. Einstein. 2016;14(2):158-77.

6. Min L, Wenger N, Walling AM, Blaum C, Cigolle C, Ganz DA, et al. When comorbidity, aging, and complexity of primary care meet: development and validation of the Geriatric Complexity of Care Index. J Am Geriatr Soc. 2013;61(4):542-50.

7. Jung HW, Yoo HJ, Park SY, Kim SW, Choi JY, Yoon SJ, et al. The Korean version of the FRAIL scale: clinical feasibility and validity of assessing the frailty status of Korean elderly. The Korean $\mathrm{J}$ Intern Med. 2016;31(3):594-600.

8. Panza F, Solfrizzi V, Lozupone M, Barulli MR, D'Urso F, Stallone R, et al. An old challenge with new promises: a systematic review on comprehensive geriatric assessment in long-term care facilities. Rejuvenation Research. 2018;21(1):3-14.

9. Campos CA, Gama CC, Carvalho JPSS, Neves JM, Carneiro MGC, Costa MC, et al. Levantamento de vulnerabilidades funcionais em idosos: possibilidades de atuação para a atenção primária à saúde. Sinapse Múltipla. 2017;6(2):235-40.

10. Morley JE, Little MO, Berg-Weger M. Rapid geriatric assessment: a tool for primary care physicians. J Am Dir Assoc. 2017;18(3):195-9.

11. Morley JE, Arai H, Cao L, Dong B, Merchant RA, Vellas B, et al. Integrated care: enhancing the role of the primary health care professional in preventing functional decline: a systematic review. J Am Med Dir Assoc. 2017;18(6):489-94.

12. Veras RP. Prevenção de doenças em idosos: os equívocos dos atuais modelos. Cad Saúde Pública. 2012;28(10):1834-40.

13. Silveira MB, Saldanha RP, Leite JCC, Silva TOF, Silva T, Filippin LI. Construção e validade de conteúdo de um instrumento para avaliação de quedas em idosos. Einstein. 2018;16(2):eAO4154.

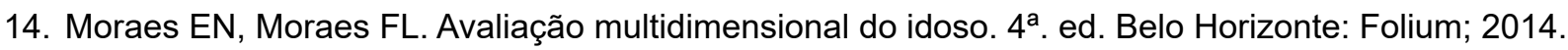

15. Banhato EFC, Ribeiro PCC, Guedes DV, Mármora CHC, Lourenço RA. Health self-awareness in senior citizens: focus on physical, emotional and cognitive health. Psychology. 2015;6(7):846-55.

16. Confortin SC, Giehl MWC, Antes DL, Schneider IJC, d'Orsi E. Autopercepção positiva de saúde em idosos: estudo populacional no Sul do Brasil. Cad Saúde Pública. 2015;31(5):1049-60.

17. Souza F, Dias AM. Condição multidimensional de saúde dos idosos inscritos na Estratégia Saúde da Família. Arq Ciênc Saúde. 2015;22(4):73-7.

18. Poubel PB, Lemos ELC, Araújo FC, Leite GG, Freitas IS, Silva RMA, et al. Autopercepção de saúde e aspectos clínico-funcionais dos idosos atendidos em uma unidade básica de saúde no norte do Brasil. J Health Biol Sci (Online). 2017;5(1):71-8.

19. Kuosmanen K, Rovio S, Kivipelto M, Tuomilehto J, Nissinem A, Kulmala J. Determinants of self-rated health and self-rated physical fitness in middle and old age. Europ J Ment Health. 2016;11(1-2):128-43.

20. Bamia C, Orfanos $P$, Juerges $H$, Schöttker, B, Brenne, $H$, Lorbeer $R$, et al. Self-rated health and all-cause and cause-specific mortality of older adults: individual data meta-analysis of prospective cohort studies in the CHANCES Consortium. Maturitas. 2017;103:37-44.

21. Ribeiro EG, Matozinhos FP, Guimarães GL, Couto AM, Azevedo RS, Mendoza IYQ. Self-perceived health and clinical-functional vulnerability of the elderly in Belo Horizonte/Minas Gerais. Rev Bras Enferm. 2018;71(supl 2):860-67. 
22. Ibanez G, Mercedes BPC, Vedana KGG, Miasso Al. Adesão e dificuldades relacionadas ao tratamento medicamentoso em pacientes com depressão. Rev Bras Enferm. 2014;67(4):556-62.

23. Mello AC, Engstrom EM, Alves LC. Health-related and socio-demographic factors associated with frailty in the elderly: a systematic literature review. Cad Saúde Pública. 2014;30(6):1143-68.

24. Melo BRS, Diniz MAA, Casemiro FG, Figueiredo LC, Santos-Orlandi AA, Haas VJ, et al. Avaliação cognitiva e funcional de idosos usuários do serviço público de saúde. Esc Anna Nery Rev Enferm. 2017;21(4):e201603881-8.

25. Jesus ITM, Orlando FS, Zazzetta MS. Frailty and cognitive performance of elderly in the context of social vulnerability. Dement Neuropsychol. 2018;12(2):173-80.

26. Prince MJ, Wu F, Guo Y, Gutierrez Robledo LMG, O'Donnel M, Sullivan R, et al. The burden of disease in older people and implications for health policy and practice. Lancet. 2015;385(9967):549-62.

27. Sadana R, Soucat A, Beard J. Universal health coverage must include older people. Bull World Health Org [Internet]. 2018 [acesso em 2018 Set 03];96(1):1-76. Disponível em: http://www.who.int/bulletin/ volumes/96/1/17-204214/en/

28. Morais ONP. Grupos de idosos: atuação da psicogerontologia no enfoque preventivo. Psicol Ciênc Prof. 2009;29(4):846-55.

29. Veras RP. Experiências e tendências internacionais de modelos de cuidado para com o idoso. Ciênc Saúde Coletiva. 2012;17(1):231-38.

30. Soares SM, Ferraz AF. Grupos operativos de aprendizagem nos serviços de saúde: sistematização de fundamentos e metodologias. Esc Anna Nery Rev Enferm. 2017;11(1):52-7.

\section{Author for correspondence:}

Pricila Cristina Correa Ribeiro

Universidade Federal de Minas Gerais

Departamento de Psicologia

Avenida Antônio Carlos, 6627

Bairro: Pampulha

CEP: 31270-901 - Belo Horizonte - MG - Brasil

E-mail: pricilaribeiro@ufmg.br

How to cite: Ribeiro PCC, Neves ACC, Reis JC, Damaso ALA, Barros VC. Clinical-functional vulnerability in older adults and its impact on primary health care actions. Rev Bras Promoç Saúde. 2019;32:8366. 